\title{
Research on self-esteem in decision-making and decision-making styles in orienteering athletes
}

\author{
Başak Eroğlu ${ }^{1 \mathrm{a}}$, Zekiye Özkan ${ }^{2}$, Arif Kaan Eroğlu ${ }^{2}$, and Şakire Bilgin ${ }^{2}$ \\ ${ }^{1}$ Namık Kemal University College of Physical Education and Sports, 59000,Tekirdağ, Turkey \\ ${ }^{2}$ Yüzüncü Y1l University College of Physical Education and Sports, 65100,Van, Turkey
}

\begin{abstract}
The aim of this study is to examine the self-esteem in decision making and decision-making styles of orienteering athletes in terms of different variables. 157 male and 43 female orienteering athletes, making a total of 200 athletes that joined the 3rd Level of Turkey Championship in 2015 have participated in this study which is in a survey model. The data collection tools were the Melbourne Decision-making. Quastionnaire I-II and the Personal Information Form which were adapted into Turkish by Deniz (2004). In the data analysis, descriptive statics, anova, $t$ test and Tukey test have been utilized. There is a significant difference between athletes' marital status, age groups, experiences in orienteering sports and self-esteem in decision making, decision making styles $(\mathrm{p}<0.05)$. According to the research results, it has been determined that married orienteering athletes prefer both self-esteem in decision making and vigilance decision-making style more often than the single athletes that mostly prefer procrastination decision-making style. Also, it has been found out that as the athletes' age and experiences in sports increase, selfesteem and decision-making styles are affected more positively as well.
\end{abstract}

\section{Introduction}

Cognitive psychologists use the concept of "decision making" for the expression of mentations occurred in the selection among different alternatives [16]. The approach of classical decision making is consisted of five stages including determination of the target, collection of information related with the subject, formation of possible choices, making decision, implementation of the decision, and assessment [2].

Sports environment presents an excellent opportunity for decision making studies. Decision making in sports covers some different factors (trainers, players), their duties (such as possession of the ball) and their contents (throughout the game and between

${ }^{\text {a }}$ Corresponding author: beroglu@yyu.edu.tr 
games). There are three important properties of decision making in sports; it is natural, it is dynamic and most of the time the decisions are suppressed under high time [17].

The talent of decision making is one of the factors that determine the sports talent [13]. This talent of athletes is also determined by a great number of stimulants in the environment and total amount of possible motions [24,25]. A successful decision making necessitates both speed and perfect-accurate motion. If the athletes decide true answer, the opportunities for being successful increase incrementally [11]. Perception, decision making mechanism and factors forming instinction can be developed by training. If these talents are enhanced, a competition experience at a significant level will be gained $[1,11,14]$.

The most significant property of orienteering branch is to track the best route in an unknown field against time and to find the target in the shortest time. This necessitates rapid decision making talent [18]. Stress [10], having many choices [22], limited time and information [8] are the factors that complicate decision making. Situations emerging the decision making behaviour such as prudential predictions, selecting "the best one" among two or more alternatives or reasoning based on limited or non-objective information [21] are most commonly encountered in orienteering sports.

\subsection{The Aim of the Research}

The main purpose of this study was to investigate self-esteem in decision making and decision making styles of orienteering athletes in terms of different variables.

\subsection{The Problem of the Research}

It was aimed to find out whether decision making and decision making styles of orienteering athletes have effect their self-esteem.

\section{Method}

In this research as scanning model, 200 orienteering athletes at different age categories including 157 males and 43 females who participated in 2015 Turkish Championship 3rd stage competitions 2015.

The data collection tools were the Melbourne Decision-making. Quastionnaire I-II, developed by Mann and et al., (1998) and the Personal Information Form which were adapted into Turkish by Deniz (2004) [23.9].

Ist part of Melbourne Decision Making Scale having two parts constituted of 6 items and single sub-factor aiming to determine self-esteem in decision making. IInd part, on the other hand, constituted of 22 items and four sub-factors aiming to determine decision making styles. These sub-factors are vigilance (6 items), buck-passing (6 items), procrastination (5 items) and hypervigilance (5 items) decision making styles. Grading was calculated as 2 points for "Correct" answer, 1 point to "Sometimes Correct" answer and 0 point to "Not Correct" answer given to the items. High grades indicate that related decision making style was used [23].

In this research, t-test and one-way variance analysis (Anova) depending on variables were used to determine whether self-esteem in decision making and decision making styles of orienteering athletes differentiate or not significantly in terms of different variables (gender, age, marital status, educational status, educational status of mother-father, level of income, sports age, years of experience in orienteering sports, being national, sportive success). Tukey test was applied in order to determine the source of differentiation. 


\section{Findings}

In the research, self-esteem in decision making (8.4 \pm 1.61$)$ together with vigilance (9.55 \pm 2.14$)$, buck-passing (3.75 \pm 2.78$)$, procrastination (3.09 \pm 2.15$)$ and hypervigilance $(3.12 \pm 2.2)$ decision making styles of orienteering athletes were evaluated.

A significant difference was found between marital status and self-esteem in decision making, vigilance decision making style and procrastination decision making style of athletes $(\mathrm{p}<0.05)$. The self-esteem in decision making levels of married orienteering athletes $(\overline{\mathrm{X}}=9.18 \pm 1.07)$ were higher than single orienteering athletes. In the research, it was determined that married athletes used their vigilance decision making style $(\overline{\mathrm{X}}=10.55 \pm 1.47)$ more and preferred their procrastination decision making style $(\overline{\mathrm{X}}=2.25 \pm 1.55)$ less when compared to single athletes (Table 1).

-Table 1. Self-esteem in decision making and decision making styles of orienteering athletes in terms of their marital status

\begin{tabular}{|c|c|c|c|c|}
\hline Decision making & Marital status & $\mathbf{N}$ & $\overline{\mathbf{X}} \pm \mathbf{S D}$ & p \\
\hline \multirow{2}{*}{ Self-esteem } & Married & 27 & $9.18 \pm 1.07$ & \multirow{2}{*}{$0.00 *$} \\
\hline & Single & 173 & $8.27 \pm 1.65$ & \\
\hline \multirow{2}{*}{ Vigilance } & Married & 27 & $10.55 \pm 1.47$ & \multirow{2}{*}{$0.00^{*}$} \\
\hline & Single & 173 & $9.36 \pm 2.18$ & \\
\hline \multirow{2}{*}{ Buck-passing } & Married & 27 & $2.77 \pm 1.55$ & \multirow{2}{*}{0.05} \\
\hline & Single & 173 & $3.9 \pm 2.85$ & \\
\hline \multirow{2}{*}{ Procrastination } & Married & 27 & $2.25 \pm 1.55$ & \multirow{2}{*}{$0.03 *$} \\
\hline & Single & 173 & $3.21 \pm 2.2$ & \\
\hline \multirow{2}{*}{ Hypervigilance } & Married & 27 & $2.81 \pm 2.09$ & \multirow{2}{*}{0.44} \\
\hline & Single & 173 & $3.17 \pm 2.22$ & \\
\hline
\end{tabular}

$\left({ }^{*} \mathrm{p}<0.05\right)$
Table 2. Self-esteem in decision making and decision making styles of orienteering athletes in terms of their age

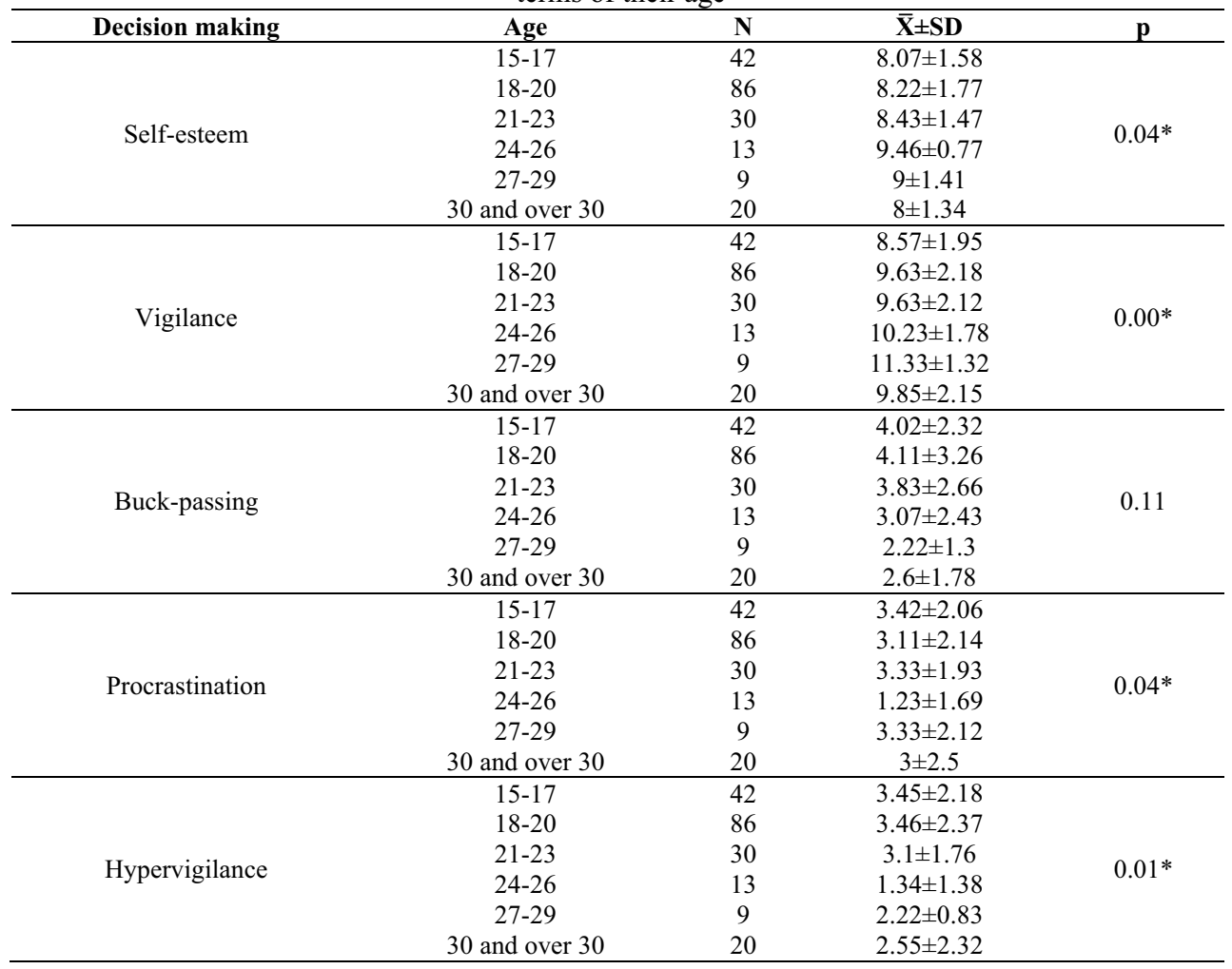


$(* \mathrm{p}<0.05)$

A significant difference was found between ages of athletes as well as self-esteem in decision making, vigilance, procrastination and hypervigilance decision making styles $(\mathrm{p}<0.05)$. It was observed that as the age level increased, vigilance decision making style was mostly preferred and procrastination as well as hypervigilance decision making styles were less preferred (Table 2).

Table 3. Self-esteem in decision making and decision making styles of orienteering athletes in terms of their experience in sports

\begin{tabular}{|c|c|c|c|c|}
\hline Decision making & Experience in sports & $\mathbf{N}$ & $\overline{\mathbf{X}} \pm \mathbf{S D}$ & $\mathbf{p}$ \\
\hline \multirow{3}{*}{ Self-esteem } & $1-3$ years & 131 & $8.06 \pm 1.69$ & \multirow{3}{*}{0.00 * } \\
\hline & 4-6 years & 35 & $8.88 \pm 1.45$ & \\
\hline & 7 years and more & 34 & $9.20 \pm 0.94$ & \\
\hline \multirow{3}{*}{ Vigilance } & $1-3$ years & 131 & $9.23 \pm 2.23$ & \multirow{3}{*}{$0.01^{*}$} \\
\hline & 4-6 years & 35 & $10.05 \pm 1.51$ & \\
\hline & 7 years and more & 34 & $10.23 \pm 2.11$ & \\
\hline \multirow{3}{*}{ Buck-passing } & $1-3$ years & 131 & $4.19 \pm 2.98$ & \multirow{3}{*}{$0.00 *$} \\
\hline & 4-6 years & 35 & $3.02 \pm 2.43$ & \\
\hline & 7 years and more & 34 & $2.79 \pm 1.85$ & \\
\hline \multirow{3}{*}{ Procrastination } & $1-3$ years & 131 & $3.40 \pm 2.11$ & \multirow{3}{*}{0.01 * } \\
\hline & $4-6$ years & 35 & $2.31 \pm 1.58$ & \\
\hline & 7 years and more & 34 & $2.67 \pm 2.53$ & \\
\hline \multirow{3}{*}{ Hypervigilance } & $1-3$ years & 131 & $3.52 \pm 2.27$ & \multirow{3}{*}{0.00 * } \\
\hline & 4-6 years & 35 & $2.51 \pm 1.80$ & \\
\hline & 7 years and more & 34 & $2.20 \pm 1.90$ & \\
\hline
\end{tabular}

$(* \mathrm{p}<0.05)$

In this research, a significant difference was found between experience of orienteering athletes in sports together with self-esteem in decision-making and decision making styles $(\mathrm{p}<0.05)$. It was determined that as the years of experience in orienteering sports increased, self-esteem in decision making levels of athletes also increased, preferred vigilance decision making style more, preferred buck-passing, procrastination and hypervigilance decision making levels less.

\section{Results and Discussion}

As a result of this research, it can be concluded that orienteering athletes generally feel confident in decision making, before making a decision and making a selection, they get necessary information and assess alternatives carefully. This finding of the research was supported by the data of sportsmen doing taekwondo in the study of Certel et al. (2013), by the data of alpinists in the study of Kaya et al. (2013), by the data of sportsmen in different branches in the study of Kelecek et al. (2013), by the data of sportsmen doing kickbox in the study of Çetin et al., (2011), by the data of students at School of Physical Education and Sports in the study of Çetin (2009) as well as by the data of sports managers in the study of Vural (2013) [5,19,20,7,6,27].

It was determined that married orienteering athletes feel more confident while making a decision, search for necessary information before making a decision carefully and make a selection after assessment of alternatives carefully; single athletes always prefer delaying, retarding and dragging out a decision without a good reason. Similar results were observed in the study of Uzunoğlu (2008) which was performed with football referees [26] ; it was indicated that buck-passing decision making style average grades of married referees were significantly lower than those of single referees. It was considered that taking responsibility 
and necessity of effective development brought with marriage positively affected self esteem in decision making and decision making process. It was observed in orienteering athletes that as age and the experience years in sports increased, self-esteem in decision making and decision making styles were positively affected. In the study of Akbulut (2012) , it was determined that football players between 17-20 years old playing professionally had lower decision making talents than those professional football 21-25 years old [3]. Moreover, Uzunoğlu (2008) indicated that young referees had escaping tendency from responsibility of decision making when they were compared with referees at older ages [26]. According to Kuzgun (2006), age was the main factor affecting decision making behaviour. With increasing age, the information and experience of individuals also increase, they behave more planned and more logically [22].

In the literature, there are many studies indicating effectiveness of sports experience on decision making. In the study of Certel et al. (2013a), self-esteem in decision making of team sportsmen having experience with 1-9 years was found lower than those having experience more than 10 years and they used buck-passing as well as hypervigilance decision making styles more [4]. Fontana (2007) indicated in his research that experienced football players made more accurate and more rapid decisions than football players having less experience [15]. It was determined by Uzunoğlu (2008) that as the ranking of football referees increased and their experience was improved, they used buck-passing and procrastination decision making styles less [26].

Different from the finding of the study, Kelecek et al. (2013) indicated that sports experience of sportsmen did not cause a change in their decision making style [20]. Egesoy (1999) did not find a significant relationship between decision speeds of elite and non-elite football players in terms of statistics [12].

Correct evaluation of attitudes of orienteering athletes during decision making process is an important criteria in increasing their performance. As mentioned by Schmidt \& Lee (2005), when it is considered that most of decision making processes in the field of sports occurred in 200 milliseconds or less than 200 milliseconds; enhancement of mental process should be evaluated as equal to other talents within training and should be added to training process by describing it as a single talent in athletic success [24]. Exercises at competition level improve self-esteem of sportsmen and adaptation capabilities of them towards new situations peculiar to sports [11].

The data indicate that; as the age and experience of orienteering athletes increase, their decision making talents also improve. Affective ageing improves self-esteem in decision making and increases the usage of positive decision making styles. Such a development can be accelerated by using training methods close to orienteering competition conditions and many competition experiences.

\section{References}

1. Abernethy, B., Wood, M. J. \& Parks, S. Can the anticipatory skills of experts be learned by novices?. Research Quarterly for Exercise and Sport, 70(3), 331-318. (1999)

2. Adair, J. E. Decision making and problem solving strategies. Kogan Page Publishers. (2007)

3. Akbulut, A. K. Amatör ve profesyonel erkek futbolcuların karar verme, problem çözme ve iletişim becerilerinin bazı değişkenler bakımından incelenmesi, Doktora Tezi, Gazi Üniversitesi, Eğitim Bilimleri Enstitüsü, Ankara, Türkiye. (2012).

4. Certel, Z. Bahadır, Z. \& Sönmez, G.T. (2013a). Takım sporları açısından empati ve karar vermede özsaygı ve karar verme stillerine yönelik bir arastırma. Niğde Üniversitesi Beden Egitimi ve Spor Bilimleri Dergisi, 7(1), 16-27. 
5. Certel, Z., Aksoy, D., Çalışkan, E., Lapa, T. Y., Özçelik, M. A. \& Çelik, G. Research on self-esteem in decision making and decision-making styles in taekwondo athletes. Procedia-Social and Behavioral Sciences, 93, 1971-1975. (2013).

6. Çetin, M. Ç. Beden eğitimi ve spor yüksekokulu öğrencilerinin karar verme stilleri, sosyal beceri düzeyleri ve stresle başa çıkma biçimlerinin bazı değişkenler açısından karşılaştırmalı olarak incelenmesi. Doktora Tezi, Gazi Üniversitesi, Ankara, Türkiye. (2009).

7. Çetin, M.Ç., Taşğın, Ö. \& Arslan, F. The relationship between reaction time and decision-making in elite kickboxing athletes. World Applied Sciences Journal, 12(10), 1826-1831. (2011).

8 Çetingüç, M. Havacılıkta karar verme. http://www.hvtd.org/yeni/?p=943 Erişim Tarihi: 10.05.2015. (2015).

9. Deniz, M. E. Investigation of the relation between decision making self-esteem, decision making style and problem solving skills of university students. Eurasian Journal of Educational Research, 4(15), 23-35. (2004).

10. Deniz, M. E. The relationships among coping with stress, life satisfaction, decisionmaking styles and decision self-esteem: an investigation with Turkish university students. Social Behavior and Personality, 34(9), 1161-1170. (2006).

11. Dowes J. \& Roozen M. Developing agility and quickness. USA: Human Kinetics, 1147. (2011).

12. Egesoy, H., Eniseler, N., Çamlıyer, H., \& Çamlıyer, H. Elit ve elit olmayan futbol oyuncularının karar verme performanslarının karar verme hızı ve verilen kararın doğruluğu açısından karşılaştırılması. CBÜ Beden Eğitimi ve Spor Bilimleri Dergisi, 3(2), 22-33. (2014).

13. Eroğlu, A. K. Farklı türdeki hareketlilik çalışmalarının basketbolculardaki bazı fizyolojik parametrelere, motorsal yeteneklere ve teknik özelliklere etkisi. Doktora Tezi, Gazi Üniversitesi, Sağlık Bilimleri Enstitüsü, Ankara, Türkiye. (2014).

14. Farrow, D. \& Abernethy, B. Can anticipatory skills be learned through implicit videobased perceptual training?, Journal of Sports Sciences, 20, 471-485. (2002).

15. Fontana, F. E. The effects of exercise intensity on decision making performance of experienced and inexperienced soccer athletes. Doctoral Thesis. University of Pittsburg, USA. (2007).

16. Galotti, K. M. Making decision that matter: how people face important life choices. Mahwah, NJ: Lawrence Erlbaum Associates Publishers. (2002).

17. Johnson, J. G. Cognitive modeling of decision making in sports. Psychology of Sport and Exercise, 7(6), 631-652. (2006).

18. Karaca, F. Başlangıçtan bitirişe oryantiring tekniği. Başbakanlık Gençlik ve Spor Genel Müdürlüğü, Türkiye Dağcılık Federasyonu. (2003).

19. Kaya, S., Kaya, S., Alkan, H., Yılmaz, İ. \& Bektaş, F. Dağcılarda kendi kendine liderlik stratejileri ile karar vermede öz saygı ve karar verme stilleri arasındaki ilişkinin değerlendirilmesi, II. Rekreasyon Araştırmaları Kongresi (31 Ekim - 03 Kasım), Aydın, 53-61. (2013).

20. Kelecek, S., Altıntaş, A. \& Așçı, F. H. Sporcuların karar verme stillerinin belirlenmesi. CBÜ Beden Eğitimi ve Spor Bilimleri Dergisi, 8(1), 21-27. (2013).

21. Kökdemir, D. Belirsizlik durumlarında karar verme ve problem çözme. Doktora Tezi, Ankara Üniversitesi, Sosyal Bilimler Enstitüsü, Ankara, Türkiye. (2003).

22. Kuzgun, Y. (2006). Meslek Gelişimi ve Danışmanlığı. (2. Baskı), Nobel Yayın Dağıtım, Ankara.

23. Mann, L., Radford, M., Burnett, P., Ford, S., Bond, M., Leung, K.,Nakamura, H., Vaughan, G. \& Yang, K. S. Cross-cultural differences in self-reported decision-making style and confidence. International Journal Of Psychology, 33, 325-335. (1998). 
24. Schmidt, R. A. \& Lee, T.D. Motor control and learning: A behavioral emphasis (4th ed.). Champaign, IL: Human Kinetics. (2005).

25. Schmidt, R. A., Wrisberg, C. A. Motor learning and performance (4th ed.). Champaign, IL: Human Kinetics. (2007).

26. Uzunoğlu, Ö. U. Türk futbol hakemlerinin karar verme stillerinin klasmanlarına ve bazı değişkenlere göre incelenmesi, Yüksek Lisans Tezi, Selçuk Üniversitesi, Sağlık Bilimleri Enstitüsü, Konya, Türkiye. (2008).

27. Vural, M. Spor genel müdürlüğü merkez ve taşra teşkilatında görev yapan spor yöneticilerinin düşünme ve karar verme stillerinin incelenmesi. Yüksek Lisans Tezi, Selçuk Üniversitesi, Sağlık Bilimleri Enstitüsü, Konya, Türkiye. (2013). 